\title{
Differences in fine-scale genetic structure and dispersal in Quercus ilex L. and Q. suber L.: consequences for regeneration of mediterranean open woods
}

\author{
A Soto, Z Lorenzo and L Gil \\ Unidad Mixta de Genética y Ecofisiologia Forestal INIA-UPM, Departamento Silvopascicultura, Universidad Politécnica de Madrid, \\ E.T.S.I. de Montes, U.P.M. Ciudad Universitaria, Madrid, Spain
}

\begin{abstract}
Cork oak (Quercus suber L.) and holm oak (Q. ilex L.) are among the most important tree species (economically and ecologically) in the Western Mediterranean region, where they define unique open woods (created and maintained by man) known as 'dehesas' in Spain. However, these formations are under increasing threat due to the lack of regeneration. We have analysed spatial genetic structure in a mixed parkland; inferences about gene dispersal have also been performed, according to the isolation by distance model. Noticeable differences have been detected between the species, despite their similar ecological roles. Restricted effective dispersal leads to kin structures in cork oak, up to $70 \mathrm{~m}$, while no genetic structure is observed in holm oak. Our results suggest a very effective dispersal for the latter, with a local historical gene
\end{abstract}

flow estimated between 55 and $95 \mathrm{~m}$. This is the first time regeneration of Mediterranean oak parklands has been assessed from a genetic perspective. Effective gene flow detected for holm oaks allows us to discount the risk of inbreeding over successive generations. Thus, regeneration of $Q$. ilex dehesas will just require action directed to help the settlement of the saplings (such as limiting grazing). However, in those cases where densities are too low, more intense forestation (such as plantation and/or establishment of appropriate shelter) will be needed. The 'density threshold' for initiating regeneration will probably be higher for cork oak, due to its more limited dispersal and minor full-light tolerance. Heredity(2007) 99, 601-607; doi:10.1038/sj.hdy.6801007; published online 31 October 2007

Keywords: Quercus ilex; Quercus suber, mediterranean open woods; regeneration; gene dispersal; spatial genetic structure

\section{Introduction}

The abundance of evergreen broad-leaved trees such as Quercus suber L. (cork oak) and Quercus ilex L. (holm oak) characterizes European schlerophyllous forests. Both tree species are among the most important from an ecological point of view in the Western Mediterranean basin, and dominate formations in extended areas along the region. Open wooded landscapes of these species are particularly abundant in Spain and Portugal, where they are known as 'dehesas' and 'montados' respectively, and can also be found in France, Italy and Greece (in this case, just $Q$. ilex). These are formations created and maintained for the activities carried out in the clearings and under the canopies, such as cropping and grazing; remaining trees provide acorns, highly regarded as pig food. The oldest dehesas, still existing, were created in the Middle Ages and are named 'dehesas boyales' in Spain. Since the nineteenth century, cork exploitation became an addi-

Correspondence: $\operatorname{Dr}$ A Soto, U.D. Anatomía, Fisiología y Genética, Departamento Silvopascicultura, Universidad Politécnica de Madrid, E.T.S.I. de Montes, Ciudad Universitaria, s/n. 28040 Madrid, Spain.

E-mail: alvaro.soto.deviana@upm.es

Received 11 September 2006; revised 12 April 2007; accepted 25

April 2007; published online 31 October 2007 tional key factor in their economic value; these agrosilvipastoral systems developed extensively in those years and are named 'majadales' (see Martín-Vicente and Fernández-Alés (2006), for a review of the history of Spanish dehesas). In recent years, there has been increasing recognition of the important contribution made by these systems to the preservation of seminatural habitats and landscapes in Europe. High levels of species richness have been reported (Blondel and Aaronson, 1999), leading to their inclusion as special areas of conservation in EU directive 92/43; they are considered as the paradigm of sustainable agrosilvicultural equilibrium (Council of Europe, UNEP \& ECNC 1996; Joffre et al., 1999). However, Iberian dehesas are currently threatened by the lack of regeneration (mainly due to the excess of grazing and insolation) and they cannot rely exclusively on the decreasing resprouting ability of decaying, aged adult trees (Pulido and Díaz, 2005). Thus, their admired sustainability is jeopardized, and these formations may become 'fossil forests'. In this sense, the outlook is more favourable for $Q$. ilex. This is a more euryoic species than $Q$. suber (whose presence is limited by cold, drought and soil type). Q. ilex is also a more resilient species, with a better tolerance for direct insolation and with very effective asexual reproduction through stump and root shooting. Recently, several 
studies on the regeneration of Mediterranean forest have been published (reviewed in Jordano et al., 2004), and some of them are centred on $Q$. ilex and $Q$. suber (Plieninger et al., 2003, 2004; Pulido and Díaz, 2005; Pausas et al., 2006; Pons and Pausas, 2006). However, these works have focused mainly on ecological aspects of regeneration, silviculture and land use, without addressing the genetic issues of dehesa regeneration. Other previous work related to the reproduction of these two species has focused on their mating system and hybridization (for instance, Elena-Rosselló et al., 1992; Michaud et al., 1992; Belahbib et al., 2001; Boavida et al., 2001). Our aim is to check if these more robust characteristics of $Q$. ilex are coupled with more effective gene dispersal, which would suggest that its regeneration would be more feasible in open parklands than for Q. suber. Research on this subject will give insight into processes such as the establishment of sibling neighbourhoods and will help to provide reasonable guidelines for wood management and conservation strategies. As an initial contribution in this direction, this work focuses on spatial genetic structure in a mixed $Q$. ilex-Q. suber population and on inferences regarding historical gene flow for both species.

The genetic structure of populations is largely mediated by the reproductive strategies of the species and by their management. Some studies have been performed on other species of the genus: for instance, Q. rubra (Sork et al., 1993) or Q. laevis (Berg and Hamrick, 1995) in North America, or Q. acutissima (Chung et al., 2002) in Asia. In Europe, Streiff et al. (1998) and Cottrell et al. (2003) have described the fine-scale genetic structure of different stands of $Q$. petraea (Matt.) Liebl. and $Q$. robur L. in France and Scotland. Nevertheless, certain reproductive aspects may be different in evergreen species than in deciduous ones (for instance, pollen dispersal, due to the shielding by the leaves). The forest management of these temperate species of white oaks also differs considerably from our study species in dehesas and montados. Thus, a different genetic structure would be expected, a priori, for $Q$. ilex and $Q$. suber open parklands.

\section{Materials and methods}

\section{Study site}

A 11.3 ha study plot has been established in a typical dehesa, located in Central Spain $\left(40^{\circ} 20^{\prime} \mathrm{N}, 7^{\circ} 00^{\prime} \mathrm{W}\right)$, in which $Q$. ilex and $Q$. suber share the canopy layer and there are virtually no shrub species present. We have used as study plot an area fenced 20 years ago to prevent grazing, easing regeneration, in a relatively dense area of the wood (38.3 Q. ilex adult trees/ha and 85.2 Q. suber adult trees/ha) (Figure 1). In the western part of the plot $Q$. ilex predominates, merging with $Q$. suber towards the central part. Q. suber is dominant in the eastern part. In the study plot there are abundant old trees whose bark has been stripped several times.

Trees with less than $15 \mathrm{~cm}$ of diameter at breast height (dbh) were classified as 'immature' or non-reproductive (field observations). An uneven distribution of dbh was detected, mainly for $Q$. suber, with a low proportion of younger stems, probably due to an insufficient regeneration. Taking into account the large age range in the

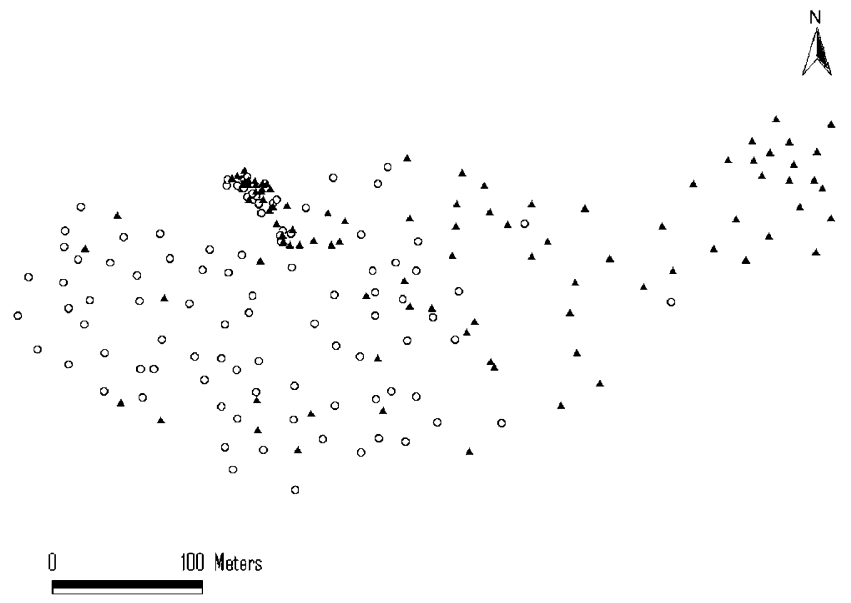

Figure 1 Distribution of sampled trees in the study plot. Q. ilex are indicated by open circles, and $Q$. suber by black triangles.

reproductive class (dbh ranging from 15 to $91 \mathrm{~cm}$ for Q. ilex and up to $134 \mathrm{~cm}$ for Q. suber), adult individuals were classified into two groups, according to a gap observed in $\mathrm{dbh}$ distribution: younger reproductive individuals $(15 \mathrm{~cm}<\mathrm{dbh}<50 \mathrm{~cm})$ and older adults $(\mathrm{dbh}>50 \mathrm{~cm})$.

\section{Sampling of trees}

A total of $95 Q$. ilex and 96 Q. suber were sampled, following a two-level design: throughout the plot, leaves from adult trees $(\mathrm{dbh}>15 \mathrm{~cm})$, separated by approximately $10-15 \mathrm{~m}$ were collected, while, to investigate the relationships of the immature, 18 and 12 young stems of $Q$. ilex and $Q$. suber respectively were sampled within a $40 \times 30 \mathrm{~m}$ area in the central part of the study plot, where saplings are concentrated (Figure 1). Regarding reproductive individuals, the sampling effort represents approximately $15 \%$ of the trees of $Q$. ilex and $10 \%$ of $Q$. suber. Thirty-eight of the $Q$. ilex and $37 Q$. suber samples were classified as older adults $(\mathrm{dbh}>50 \mathrm{~cm})$ while 39 and 47, respectively, as younger adults.

Spatial position (UTM coordinates) was recorded (with 0-5 m precision) for each sampled tree using a GPS, GeoExplorer 3 (Trimble Company, Sunnyvale, CA, USA), and corrected with Madrid's base station.

\section{SSR amplification and analysis}

DNA was extracted from leaves following the method described by Doyle and Doyle (1990). A total of nine $(\mathrm{GA})_{\mathrm{n}}$ nuclear microsatellites were used, transferred from other Quercus species: MSQ4 and MSQ13 (first described in $Q$. macrocarpa Michx. (Dow et al., 1995)) QpZAG9, QpZAG15, QpZAG36, QpZAG46 (developed in Q. petraea (Matts.) Liebl. (Steinkellner et al., 1997)), QrZAG7, QrZAG11 and QrZAG20 (Q. robur L. (Kampfer et al., 1998)). Amplification and scoring of the first six microsatellites were performed following Soto et al. (2003). The same stoichiometric conditions were used for QrZAG7, QrZAG11 and QrZAG20 and the standard amplification profile described in that work was also used for QrZAG11. Twenty cycles, with an annealing step at $57^{\circ} \mathrm{C}$, were used to amplify QrZAG7. A touchdown procedure was followed for QrZAG20, decreasing annealing temperature from 65 to $55^{\circ} \mathrm{C}\left(0.5^{\circ} \mathrm{C} /\right.$ cycle $)$, 
and 15 additional cycles at $55^{\circ} \mathrm{C}$ as annealing temperature.

\section{Statistical analysis}

Genetic diversity: Genetic diversity of the $Q$. ilex and $Q$. suber population was evaluated through the observed heterozygosity $\left(H_{\mathrm{o}}\right)$, expected heterozygosity $\left(H_{\mathrm{e}}\right)$, effective number of alleles $\left(A_{\mathrm{e}}=1 /\left(1-H_{\mathrm{e}}\right)\right)$, allelic frequency and fixation index $\left(F=1-\left(H_{\mathrm{o}} / H_{\mathrm{e}}\right)\right)$, according to Nei (1978).

Spatial autocorrelation analysis: isolation by distance: Limited dispersal can lead to reproductive isolation by distance, producing 'pedigree structures' within plant populations. In the present study, this feature was tested using the 'relatedness' approach of Hardy and Vekemans (1999), according to which, in an isotropic bidimensional habitat, the pairwise relationship between individuals is expected to vary linearly with the logarithm of the physical distance. To check the presence of such 'familial neighbourhoods' we analysed the correlation coefficient between allelic states proposed by John Nason (Loiselle et al., 1995). It was calculated for ten 25-m pairwise distance classes (from 0 to $250 \mathrm{~m}$ ) using the software SPAGeDi 1.2 (Hardy and Vekemans, 2002). The Nason's kinship coefficient value provided by the software for the $0 \mathrm{~m}$ distance class is an estimator of inbreeding. In all cases, significance of these parameters vs random distribution was tested permuting 10000 times the multiloci genotypes among the positions of the sampled trees.

Finally, the plot was subdivided in a $50 \times 50 \mathrm{~m}$ grid, and differentiation statistics (F-statistics) were calculated for the resulting subpopulations. Isolation by distance was studied for the resulting subpopulations following
Hardy and Vekemans (1999), making use of same approach that was used for individuals.

Standard errors for multilocus estimators were obtained by jack-knifing among loci. The spatial range and distance classes that were considered fulfilled the statistical requirements recommended by the software authors.

Under isolation by distance, neighbourhood size can be defined as $N b=4 \pi d_{e} s^{2}$, where $d_{e}$ is the effective population density and ' $s$ ' is the mean square distance of gene dispersal. Vekemans and Hardy (2004) proposed a $S p$ statistic to estimate $1 / 4 \pi d_{e} S^{2}$, which can be calculated as $S p \approx b /(F-1)$, where $F$ is the inbreeding coefficient (in the present case, we used Nason's coefficient) and $b$ is the regression slope based on the logarithm of spatial distance. This is a convenient parameter for assessing genetic structure and for comparing it among species, independent of the sampling performed (Vekemans and Hardy, 2004). To estimate the extent of local gene flow we used the iterative procedure implemented in the software, following Fenster et al. (2003). Since a good estimate of the historical $d_{\mathrm{e}}$ value is virtually unobtainable for long-lived forest trees, we have tested different values of $d_{\mathrm{e}}$ for this purpose.

\section{Results}

\section{Genetic diversity}

The diversity parameters differ substantially between both species (Table 1). A high level of polymorphism was clear for $Q$. ilex, based on the number of observed alleles per locus (mean $A_{\mathrm{o}}=13.11$ ), while for $Q$. suber this mean value was of $A_{\mathrm{o}}=5.67$. However, many of these alleles appear in low frequencies, and therefore the effective

Table 1 Diversity parameters of the study plot

\begin{tabular}{|c|c|c|c|c|c|c|c|}
\hline Locus & Species & Allele size range & $\mathrm{A}_{o}$ & $\mathrm{~A}_{e}$ & $\mathrm{H}_{e}$ & $\mathrm{H}_{o}$ & $\mathrm{~F}_{I}$ \\
\hline \multirow[t]{2}{*}{ MSQ4 } & Q. ilex & 197-201 & 3 & 1.287 & 0.2232 & $0.2316(0.0433)$ & -0.0377 \\
\hline & Q. suber & $197-217$ & 7 & 3.3782 & 0.7040 & $0.8737(0.0341)$ & -0.2411 \\
\hline \multirow[t]{2}{*}{ MSQ13 } & Q. ilex & $191-219$ & 12 & 8.149 & 0.8773 & $0.9255(0.0271)$ & -0.0550 \\
\hline & Q. suber & 219 & 1 & 1 & 0 & 0 & \\
\hline \multirow{2}{*}{ QpZAG9 } & Q. ilex & $220-257$ & 15 & 3.557 & 0.7189 & $0.6842(0.0477)$ & 0.0482 \\
\hline & $\widetilde{Q}$. suber & $225-253$ & 6 & 1.1926 & 0.1615 & $0.1277(0.0344)$ & 0.2096 \\
\hline \multirow[t]{2}{*}{ QpZAG15 } & $\widetilde{Q}$. ilex & $110-142$ & 18 & 7.919 & 0.8737 & $0.9121(0.0297)$ & -0.0439 \\
\hline & Q. suber & $122-135$ & 4 & 2.4043 & 0.5841 & $0.6421(0.0492)$ & -0.0994 \\
\hline \multirow[t]{2}{*}{ QpZAG36 } & Q. ilex & $202-251$ & 17 & 5.848 & 0.8290 & $0.8602(0.0360)$ & -0.0376 \\
\hline & Q. suber & 208-224 & 9 & 3.3463 & 0.7012 & $0.7766(0.0430)$ & -0.1076 \\
\hline \multirow[t]{2}{*}{ QpZAG46 } & Q. ilex & 166-196 & 9 & 2.911 & 0.6564 & $0.4889(0.0527)$ & 0.2552 \\
\hline & $\widetilde{Q}$. suber & 188-201 & 7 & 2.8089 & 0.6440 & $0.6809(0.0481)$ & -0.0572 \\
\hline \multirow[t]{2}{*}{ QrZAG7 } & Q. ilex & $116-142$ & 5 & 2.119 & 0.5281 & $0.9481(0.0253)$ & -0.7954 \\
\hline & Q. suber & $116-132$ & 8 & 3.4537 & 0.7105 & $0.7500(0.0462)$ & -0.0557 \\
\hline \multirow[t]{2}{*}{ QrZAG11 } & Q. ilex & $246-280$ & 15 & 8.909 & 0.8878 & $0.9362(0.0252)$ & -0.0545 \\
\hline & Q. suber & $262-274$ & 4 & 2.8525 & 0.6547 & $0.6180(0.0515)$ & 0.0560 \\
\hline \multirow[t]{2}{*}{ QrZAG20 } & $\widetilde{Q}$. ilex & $157-186$ & 24 & 13.9087 & 0.9281 & $0.9032(0.0307)$ & 0.0268 \\
\hline & Q. suber & $163-173$ & 5 & 2.0810 & 0.5081 & $0.4894(0.0516)$ & 0.0369 \\
\hline \multirow[t]{8}{*}{ Multiloci } & Q. ilex & Total & $13.11(6.62)$ & 3.6325 & $0.7247(0.0763)$ & $0.7656(0.0148)$ & -0.0564 \\
\hline & & Offspring & $7.44(3.57)$ & 3.4719 & $0.7120(0.0657)$ & $0.7921((0.0325)$ & -0.1125 \\
\hline & & Mature & $10.44(5.10)$ & 3.4980 & $0.7141(0.0842)$ & $0.7324(0.0241)$ & -0.0256 \\
\hline & & Old & $10.78(5.70)$ & 3.7782 & $0.7353(0.0765)$ & $0.7879(0.0225)$ & -0.0715 \\
\hline & Q. suber & Total & $5.67(2.45)$ & 2.0776 & $0.5187(0.0866)$ & $0.5509(0.0172)$ & -0.0622 \\
\hline & & Offspring & 3.44 (1.59) & 1.9728 & $0.4931(0.0988)$ & $0.5484(0.0490)$ & -0.1121 \\
\hline & & Mature & $5.11(1.96)$ & 2.0999 & $0.5238(0.0840)$ & $0.5424(0.0244)$ & -0.0356 \\
\hline & & Old & $4.67(2.00)$ & 2.0852 & $0.5204(0.0880)$ & $0.5647(0.0278)$ & -0.0851 \\
\hline
\end{tabular}

Abbreviations: $A_{\mathrm{o}}$, observed number of alleles; $A_{\mathrm{e}}$, effective number of alleles; $F_{\mathrm{I}}$, fixation index; $H_{\mathrm{e}}$, expected heterozygosity; $H_{\mathrm{o}}$, observed heterozygosity.

$\mathrm{SD}$ values are given in parenthesis. 
number of alleles is reduced to approximately $45-50 \%$. Expected heterozygosity ranged from 0.73 for $Q$. ilex to 0.52 for $Q$. suber. Diversity parameters do not show a great variation among cohorts, suggesting no significant bottleneck has taken place recently, although we must keep in mind the low sample size of the offspring cohort. Every tree sampled at the study site showed a unique multilocus microsatellite genotype.

\section{Spatial autocorrelation: isolation by distance and Kinship coefficients}

Relationships among trees were evaluated through Nason's kinship coefficient (Loiselle et al., 1995). No significant inbreeding was detected for any of the species, neither for the young stems (with respect to the adults), nor for the younger reproductive individuals (with respect to the older ones). Estimates were actually slightly negative (values not shown).

The existence of a genetic structure due to limited gene dispersal (isolation by distance) was also evaluated through the analysis of the spatial patterns of these pairwise relationship parameters. The relationship among trees was found to decrease gradually as the distance increases. Significant (99\%) negative slopes were obtained for $Q$. suber when all the individuals were considered, as well as for the two reproductive classes, together and independently. However, absolute values of the slopes are small ( 0.023 for all the individuals and 0.025 for reproductive ones, using $\log _{10}$ of the distance), suggesting isolation by distance has produced only weak genetic structure. When including all the individuals in the analysis, kinship is significantly higher than expected for a random distribution of the genotypes up to $75 \mathrm{~m}$ (CI 95\%). Observed values of the coefficient are, however, much lower than expected, for instance, for half sibs (0.125). This pattern does not change when younger trees are removed from analysis (Figure 2).

In contrast, the slopes of the regressions are not significantly different from zero in $Q$. ilex adults (slope $=-0.0035 \quad(P$-value 0.07$)) ;$ although significant values are obtained when young stems are included in the analysis.

The same analyses were performed exclusively on the juvenile individuals, grouped in the $40 \times 30 \mathrm{~m}$ area. Considering $10 \mathrm{~m}$ distance classes, no significant structure was detected for $Q$. suber saplings, while the $Q$. ilex showed a very slight genetic structure up to $10 \mathrm{~m}$ (data not shown); however, these results must be treated cautiously, due to the small sample size of the offspring.

When the plot was subdivided in a $50 \times 50 \mathrm{~m}$ grid, a weak but significant differentiation among squares were detected with F-statistics $\left(F_{\mathrm{ST}}=0.0238\right.$ and 0.0611 for $Q$. ilex and $Q$. suber, respectively; CI 99\%). Slopes of the regression $F_{\mathrm{ST}} /\left(1-F_{\mathrm{ST}}\right)$ vs logarithm of distance were not significantly different from zero in either case $(Q$. ilex: slope $=0.001, \quad P$-value $=0.55 ; Q$. suber: slope $=0.024$, $P$-value $=0.78$.

Neighbourhood sizes were estimated (using only adult trees) as approximately 290 and 45 individuals for Q. ilex and Q. suber, respectively. Different values of historical effective density, $d_{\mathrm{e}}$, were used to calculate the extent of local gene flow, s (Figure 3). This analysis reveals higher gene dispersal for $Q$. ilex than for $Q$. suber in all cases.

\section{Discussion}

This is the first time reproductive ecology of $Q$. ilex and $Q$. suber has been assessed from a genetic point of view, a poorly known aspect of the biology of these species, despite their prominent role in Western Mediterranean ecosystems.

The nine nuclear microsatellites used in this study as molecular markers have revealed a much greater polymorphism in $Q$. ilex than in $Q$. suber. For the latter, the average number of observed alleles is 5.67 , less than half the number for $Q$. ilex, 13.11. Expected heterozygosity was also higher for $Q$. ilex $\left(H_{\mathrm{E}}=0.725\right.$ vs 0.519 in $Q$. suber). These $H_{\mathrm{E}}$ values are intermediate between those reported for related species with different reproductive behaviours. As an example, for the two most
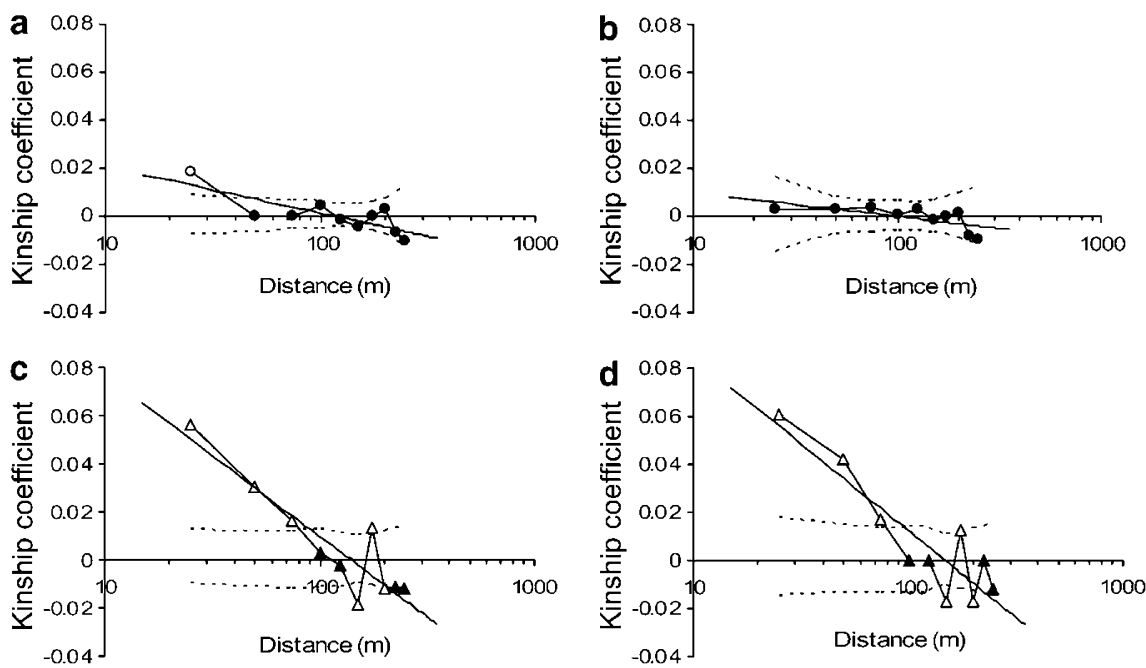

Figure 2 Isolation by distance, tested by means of linear regression of Nason's kinship coefficient (Loiselle et al., 1995) with the decimal logarithm of distance ( $25 \mathrm{~m}$ distance classes). Open symbols used for kinship values that deviate significantly from expected for a random distribution of genotypes (in dashed lines, $95 \%$ confidence interval). (a) $Q$. ilex, all the individuals; (b) $Q$. ilex, reproductive individuals; (c) Q. suber, all the individuals; (d) Q. suber, reproductive individuals. 


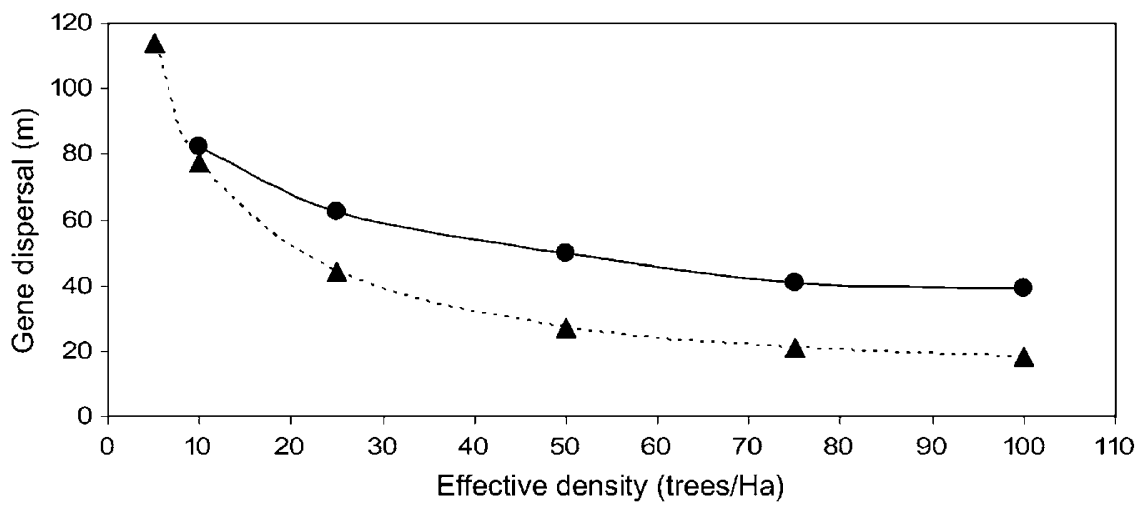

Figure 3 Historical dispersal values, considering different values of effective density $\left(d_{\mathrm{e}}\right)$ The iterative procedure yields no finite value for $Q$. ilex and an effective density of five trees/ha.

abundant white oaks in Western Europe, Q. petraea (Matts.) Liebl. and $Q$. robur L., species of strict sexual reproduction, $H_{\mathrm{E}}$ was found to be about 0.9 , in microsatellite studies in British and French populations (including four of the nine used here) (Streiff et al., 1998; Cottrell et al., 2003). On the other hand, Q. geminata Small, a species with strong clonal structure, shows much lower $H_{\mathrm{E}}$ values, about 0.3 (Ainsworth et al., 2003).

Relationship analysis and differentiation statistics support the existence of slight or moderate genetic structure for $Q$. suber. The decline of kinship estimates with distance suggests that isolation by distance has led to this structure. Nason's kinship coefficient values for adult trees suggest that familial structures spread for nearly $75 \mathrm{~m}$. However, no significant genetic structure was detected for $Q$. ilex adult trees. When including all the sampled trees, a weak structure can be detected at short distances, up to $30 \mathrm{~m}$, but after removing from the analysis younger stems, which are obviously related to the adults, no kin structure could be detected even at short distances. This is not surprising, due to the concentrated sampling of only a few young individuals, very likely resulting from few reproductive events among neighbouring adults; thus, inclusion of young individuals in the analysis yields an increase of relatedness for the first distance classes and a decrease for the higher ones.

The results for $Q$. suber contrast with most temperate forest species, for which a generally weak and narrower within-population structure has been described (Perry and Knowles, 1991; Leonardi and Menozzi, 1996; Streiff et al., 1998). For instance, within genus Quercus, Cottrell et al. (2003) report significant genetic structure for less than $40 \mathrm{~m}$ in Q. petraea (Matts.) Liebl. and Q. robur L. On an old growth stand of Turkey oak (Q. laevis Walt.), Berg and Hamrick (1995) found a genetic structure scale of $5-10 \mathrm{~m}$. However, we must bear in mind the different levels of polymorphism when interpreting these results. $Q$. suber is a much less polymorphic species than $Q$. ilex, as suggested by isozymes and cpDNA studies (Toumi and Lumaret, 1998; Jiménez et al., 1999, 2004). Regarding the present study, it could be argued that this low polymorphism can bias the results so that the observations would not reveal a real genetic structure. Yet, the risk with barely polymorphic species is to miss a real genetic structure, which would not be distinguished from a random distribution. Thus, we can be confident of the existence of such a structure in cork oak, since it was detected in spite of its low polymorphism.

On the other hand, based on the high polymorphism detected in $Q$. ilex, we can safely rule out the existence of significant genetic structure among adult trees, since it was not detected even at the shortest distances. These results suggest its genes disperse very efficiently (via pollen and seeds), resulting in the fading of detectable familial structures. This feature could be partially explained by the strong preference for holm oak acorns, vs cork oak acorns shown by foraging animals (and occasionally involuntary dispersers) such as jays and rodents (Pons and Pausas, 2007). In fact, long-distance dispersal by jays (up to one kilometre) has been reported for holm oak seeds, with an average of approximately 70 m (Gómez, 2003).

We have estimated higher historical dispersal values for $Q$. ilex than for $Q$. suber. For example, the $S p$ statistic for the former is 0.0035 , while 0.0229 for the latter. Recently Dutech et al. (2005) reported the genetic structure and made inferences regarding gene dispersal in an open wood of $Q$. lobata (a deciduous species) in California, in a situation similar to a dehesa: a formation dating from approximately 150 years ago, with an extremely low density (actually, much lower than in European dehesas, with 0.5-2.0 trees per hectare) and without regeneration. The $Q$. ilex $\mathrm{Sp}$ value is very close to that for $Q$. lobata (0.0046). Based on these $S p$ values, we can infer neighbourhood sizes of 43.6 individuals for $Q$. suber and 288.5 for $Q$. ilex (the value for $Q$. lobata would be 217.39). Dispersal distances inferred from the isolation by distance model are also higher for $Q$. ilex. However, besides other assumptions of the model (such as isotropy) the main difficulty in this inference is the estimation of historical effective density. Effective densities will depend on the census densities, on the extent of flowering time in the species, but also on other factors, such as the effective number of incompatibility alleles present in the population. Studies on this point are lacking for most species, and it is especially hard to venture an average value in long-lived species like oaks, even knowing historical census densities, since effective densities may vary across the reproductive seasons, depending on the weather conditions. The difficulty increases even more in masting species such as holm and cork oaks. For this reason, we have used a wide range of $d_{\mathrm{e}}$ values. For all cases higher gene dispersal was 
detected for $Q$. ilex and this fact, together with its higher abiotic stress tolerance and asexual reproduction confers stronger colonizing skills on the species.

A similar situation was recently analysed by ValbuenaCarabaña et al. (2005) for an abandoned mountain open wood of $Q$. petraea and $Q$. pyrenaica. In that work, more efficient gene dispersal is detected through parentage analysis for the first species, consistent with the conspicuous differences in ecological roles: $Q$. petraea is a deciduous tree with a strict sexual reproduction, while $Q$. pyrenaica is a marcescent species, with very effective root sprouting. In contrast, $Q$. ilex and $Q$. suber are more ecologically similar: the stratum they occupy, bearing, anemogamy, shape and size of the acorns, evergreen character, etc. These species occupy the canopy layer in large areas of the sclerophyll forests of the region, and silvicultural practices usually applied to forests of both species are quite similar. Nevertheless, they show some differences, in their reproductive and surviving strategies. $Q$. ilex shows a very efficient stump and root shooting, which allows recovery after grazing or fire, the most frequent disturbances in Mediterranean ecosystems. Conversely, $Q$. suber reproduces almost exclusively through allogamous mating. It endures most forest fires with the effective barrier of its thick and insulating bark, so that surviving $Q$. suber trees have an advantage over the newly establishing vegetation after fire. After recurrent perturbations, such as frequent forest fires or grazing, a stronger genetic structure, at least at short distances, could be expected for $Q$. ilex, due to its resprouting ability. However, this is not our case. In this study plot, and contrasting with the $Q$. petraea$Q$. pyrenaica situation, we have found that the effective asexual reproduction capability in $Q$. ilex is coupled with a more efficient gene dispersal, blurring familial structures.

Many factors influence the regeneration of forests, from gamete formation to incorporation to adult stages, passing through fertilization, dissemination (primary and secondary dispersion), germination and survival of seedlings and saplings (see, for instance, Rey and Alcántara, 2000; Wang and Smith, 2002, or the revision for Mediterranean forests by Jordano et al., 2004), which obviously fall out of the scope of the present work. However, from our experimental results on an aspect not yet considered for these species, we can conclude that there is very efficient long-term effective gene dispersal, especially for $Q$. ilex. Together with this proficient gene flow, our results point out a lack of significant inbreeding among the juvenile individuals, for both species. In these circumstances, the maintenance of genetic diversity in the progeny seems guaranteed; therefore, only actions directed to help the settlement of the saplings may be needed for the appropriate regeneration of these formations. Plieninger et al. (2003) discuss four alternative/ complementary strategies for Spanish dehesas regeneration, having determined that livestock and agricultural management are the main limiting factors. The authors discard the global reduction of livestock densities and farming intensities, given that the safe minimum standards would be too low to be socio-economically feasible. Other options are direct forestation and even conversion to hunting estates (with a lower herbivore pressure). The fourth strategy would consist of stopping grazing and cultivation for 20- or 30-year recovery periods in portions of the dehesa. However, most $Q$. suber and $Q$. ilex dehesas would need other interventions to ensure their regeneration, due to their extremely low densities. In these cases, seedlings are virtually absent, and regeneration takes place, if at all, by asexual sprouting. Our results suggest $Q$. ilex would regenerate more easily, given its very effective gene flow and its euryoic temperament; on the contrary, $Q$. suber would need the shelter of higher densities, given that it is a more demanding species regarding water availability and shows moderate shade tolerance (Aranda et al., 2005; Cardillo and Bernal, 2006). Taking into account its more limited dispersal, and to avoid inbreeding, some external contribution (artificial planting or sowing) would probably be advisable. Further studies are needed to obtain more accurate estimates of seed and pollen dispersal, to underpin guidelines for the restoration, conservation and management of these particular ecosystems, which are otherwise destined to disappear because of lack of regeneration.

\section{Acknowledgements}

We thank Dr Juli G Pausas at Centro de Estudios Ambientales del Mediterráneo and Celia López at Centro de Investigaciones Agropecuarias 'Dehesón del Encinar' as well as Drs Collada, Nanos (ETSIM UPM), Alía and González-Martínez (INIA) and three anonymous referees for their helpful comments and suggestions. We also thank P Hodgkinson for the language revision. This work has been partially funded by EU Project QLRT2001-01594 (CREOAK) and by the Spanish Ministry of Environment (DGB) through the covenant 'Evaluación y conservación de los recursos genéticos de los Quercus esclerófilos mediterráneos en España'.

\section{References}

Ainsworth EA, Tranel PJ, Drake BG, Long SP (2003). The clonal structure of Quercus geminata revealed by conserved microsatellite loci. Mol Ecol 12: 527-532.

Aranda I, Castro L, Pardos M, Gil L, Pardos JA (2005). Effects of the interaction between drought and shade on water relations, gas exchange and morphological traits in cork oak (Quercus suber L.) seedlings. Forest Ecol Manag 210: 117-129.

Belahbib N, Pemonge MH, Ouassou A, Sbay H, Kremer A, Petit RJ (2001). Frequent ctoplasmic exchanges between oak species that are not closely related: Quercus suber and Q. Ilex Morocco Mol Ecol 10: 2003-2012.

Berg EE, Hamrick JL (1995). Fine-scale genetic-structure of a Turkey oak forest. Evolution 49: 110-120.

Blondel J, Aaronson J (1999). Biology and Wildlife of the Mediterranean region. Oxford University Press: Oxford, UK.

Boavida LC, Silva JP, Feijo JA (2001). Sexual reproduction in the cork oak (Quercus suber L.). II. Crossing intra- and interspecific barriers. Sex Plant Repr 14: 143-152.

Cardillo E, Bernal CJ (2006). Morphological response and growth of cork oak (Quercus suber L.) seedlings at different shade levels. Forest Ecol Manage 222: 296-301.

Chung MY, Nason J, Chung MG, Kim K-J, Park C-W, Sun B-Y et al. (2002). Landscape-level spatial genetic structure in Quercus acutissima (Fagaceae). Am J Bot 89: 1229-1236.

Council of Europe, UNEP, ECNC (1996). The Pan-European Biological and Landscape Diversity Strategy - A Vision for Europe's Natural Heritage. ISBN 90-802482-4-x, Amsterdam. 
Cottrell JE, Munro RC, Tabbener HE, Milner AD, Forrest GI, Lowe AJ (2003). Comparison of fine-scale genetic structure using nuclear microsatellites within two British oakwoods differing in population history. Forest Ecol Manage 176: 287-303.

Dow BD, Ashley MV, Howe HF (1995). Characterization of highly variable $(\mathrm{GA} / \mathrm{CT}) \mathrm{n}$ microsatellites in the bur oak, Quercus macrocarpa. Theor Appl Genet 91: 137-141.

Doyle J, Doyle J (1990). Isolation of plant DNA from fresh tissue. Focus 13: 13-15.

Dutech C, Sork VL, Irwin AJ, Smouse PE, Davis FW (2005). Gene flow and fine-scale genetic structure in a windpollinated tree species Quercus lobata (Fagaceae). Am J Bot 92: 252-261.

Elena-Rosselló JA, Lumaret R, Cabrera E, Michaud H (1992). Evidence of hybridization between sympatric holm-oak and cork-oak in Spain based on diagnostic enzyme markers. Plant Ecol 99-100: 115-118.

Fenster CB, Vekemans X, Hardy OJ (2003). Quantifying gene flow from spatial genetic structure data in a metapopulation of Chamaecrista fasciculata (Leguminosae). Evolution 57: 995-1007.

Gómez JM (2003). Spatial patterns in long distance dispersal of Quercus ilex acorns by jays in a heterogeneous landscape. Ecography 26: 573-584.

Hardy OJ, Vekemans X (1999). Isolation by distance in a continuous population: reconciliation between spatial autocorrelation analysis and population genetics models. Heredity 83: $145-154$.

Hardy OJ, Vekemans X (2002). SPAGEDi: a versatile computer program to analyse spatial genetic structure at the individual or population levels. Mol Ecol Notes 2: 618-620.

Jiménez P, Agúndez D, Alía R, Gil L (1999). Genetic variation in central and marginal populations of Quercus suber L. Silvae Genet 48: 278-284.

Jiménez P, Lopez de Heredia U, Collada C, Lorenzo Z, Gil L (2004). High variability of chloroplast DNA in three Mediterranean evergreen oaks indicates complex evolutionary history. Heredity 93: 510-515.

Joffre R, Rambal S, Ratte JP (1999). The dehesa system of southern Spain and Portugal as a natural ecosystem mimic. Agroforest Syst 45: 57-79.

Jordano P, Pulido F, Arroyo J, García-Castaño JL, García-Fayos P (2004). Procesos de limitación demográfica. In: Valladares, F (ed). Ecología Del Bosque Mediterráneo en un Mundo Cambiante. Ministerio de Medio Ambiente, Madrid. pp 229-248.

Kampfer S, Lexer C, Glössl J, Steinkellner H (1998). Characterization of $(\mathrm{GA})_{\mathrm{n}}$ microsatellite loci from Quercus robur. Hereditas 129: 183-186.

Leonardi S, Menozzi P (1996). Spatial structure of genetic variability in natural stands of Fagus sylvatica L (beech) in Italy. Heredity 77: 359-368.

Loiselle BA, Sork VL, Nason J, Graham C (1995). Spatial genetic structure of a tropical understory shrub, Psychotria officinalis (Rubiaceae). Am J Bot 82: 1420-1425.
Martín-Vicente A, Fernández-Alés R (2006). Long term persistence of dehesas. Evidences from history. Agroforestry Syst 67: 19-28.

Michaud H, Lumaret R, Romane F (1992). Variation in the genetic structure and reproductive biology of holm oak populations. Plant Ecol 99-100: 107-113.

Pausas JG, Ribeiro E, Dias SG, Pons J, Beseler C (2006). Regeneration of a marginal cork oak (Quercus suber) forest in the eastern Iberian Peninsula. J Veget Sci 17: 729-738.

Perry DJ, Knowles P (1991). Spatial genetic structure within 3 sugar maple (Acer saccharum Marsh) stands. Heredity 66: 137-142.

Plieninger T, Pulido FJ, Konold W (2003). Effects of land-use history on size structure of holm oak stands in Spanish dehesas: implications for conservation and restoration. Environ Conserv 30: 61-70.

Plieninger T, Pulido FJ, Schaich H (2004). Effects of land-use and landscape structure on holm oak recruitment and regeneration at farm level in Quercus ilex L. dehesas. J Arid Environ 57: 345-364.

Pons J, Pausas JG (2006). Oak regeneration in heterogeneous landscapes: the case of fragmented Quercus suber forests in the eastern Iberian Peninsula. Forest Ecol Manage 231: 196-204.

Pons J, Pausas JG (2007). Rodent acorn selection in a Mediterranean oak landscape. Ecol Res 22: 535-541.

Pulido FJ, Díaz M (2005). Regeneration of a Mediterranean oak: a whole cycle approach. Ecoscience 12: 92-102.

Rey PJ, Alcántara JM (2000). Recruitment dynamics of a fleshyfruited plant (Olea europaea): connecting patterns of seed dispersal to seedling establishment. J Ecol 88: 622-633.

Soto A, Lorenzo Z, Gil L (2003). Nuclear microsatellite markers for the identification of Quercus ilex L. and Q. suber L. hybrids. Silvae Genet 52: 63-66.

Steinkellner H, Fluch S, Turetschek E, Lexer C, Streiff R, Kremer A et al. (1997). Identification and characterization of (GA/CT) n-microsatellite loci from Quercus petraea. Plant Mol Biol 33 1093-1096.

Streiff R, Labbe T, Bacilieri R, Steinkellner H, Glossl J, Kremer A (1998). Within-population genetic structure in Quercus robur L. and Quercus petraea (Matt.) Liebl. assessed with isozymes and microsatellites. Mol Ecol 7: 317-328.

Toumi L, Lumaret R (1998). Allozyme variation in cork oak (Quercus suber L.): the role of phylogeography and genetic introgression by other Mediterranean oak species and human activities. Theor Appl Genet 97: 647-656.

Valbuena-Carabaña M, González-Martínez SC, Sork VL, Collada C, Soto A, Goicoechea PG et al. (2005). Gene flow and hybridisation in a mixed oak forest (Quercus pyrenaica Willd. and Q. petraea (Matts.) Liebl.) in central Spain. Heredity 95: $457-465$.

Vekemans X, Hardy OJ (2004). New insights from fine-scale spatial genetic structure analyses in plant populations. $\mathrm{Mol}$ Ecol 13: 921-935.

Wang BC, Smith TB (2002). Closing the seed dispersal loop. Trends Ecol Evol 17: 379-385. 